\title{
Adult-Onset Langerhans Cell Histiocytosis And The Role of Vinblastine In The Treatment -Ankara Oncology Hospital Experience
}

\section{Erişkin Başlangıçı Langerhans Hücreli Histiyositozis Tedavisinde Vinblastin Kemoterapisinin Yeri - Ankara Onkoloji Hastanesi Deneyimi}

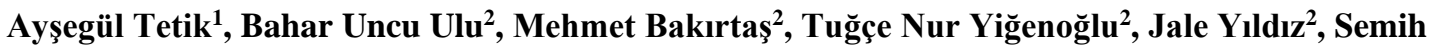 \\ Başcı' $^{2}$, Hikmettullah Batgi ${ }^{2}$, Nuran Ahu Baysal' ${ }^{2}$, Dicle İskender², Merih Kızıl Çakar², Mehmet Sinan \\ Dal $^{2}$, Fevzi Altuntas ${ }^{2}$ \\ ${ }^{1}$ İstanbul Eğitim Ve Araştırma Hastanesi, Hematoloji Kliniği,istanbul \\ ${ }^{2}$ Sağlık Bilimleri Üniversitesi, Dr. Abdurrahman Yurtaslan Ankara Onkoloji Eğitim Ve Araştırma Hastanesi, \\ Hematoloji Ve Kemik İliği Nakil Kliniği, Ankara
}

\section{ÖZET}

GİRISŞ ve AMAÇ: Langerhans hücreli histiyositozis atipik histiyositlerin lokal veya yaygın olarak kemik, hipofiz bezi, lenf nodları,akciğerler ve merkezi sinir sistemi gibi çeşitli dokularda klonal neoplastik çoğalması karakterize bir hastalık grubudur. Merkezimizde takip edilen sekiz LHH olgusu klinik, laboratuvar ve sağkalım açısından retrospektif olarak değerlendirilmesi ve tedavide vinblastin kemoterapisinin rolünün incelenmesi amaçlanmıştır.

YÖNTEM ve GEREÇLER: Mayıs 2011 - Eylül 2019 tarihleri arasında takipli 8 hastanın verileriler retrospektif olarak değerlendirilmiştir.

BULGULAR: Sekiz hastanın ortalama yaşı 37 (en küçük 19-en büyük 75) dir. Erkek / kadın oranı 7/1'dir. Hastaların en sık başvuru şikayeti \%50 oranında kemik ağrısıydı. Hastaların klinik evrelemesinde \%62.5 'sinin tek sistem tutulumu olduğu; \%37.5'inin multi-sistem tutulumu saptand. Tek sistem tutulumlu hastaların \%60'ında tutulum yeri nedeniyle santral sinir sistemi invazyonu açısından riskli bölgelere yerleştiği görülerek yüksek risk sınıfında değerlendirildi. Tanı amaçlı cerrahi rezeksiyon, tek sistem tutulu $\% 25$ hastada tedavi olarak da değerlendirilmiştir. Kemoterapi olarak ilk basamakta \%37.5 hastada, \%12.5 hastada ikinci basamakta vinblastin + metilprednizolon tedavisi tercih edilmiştir. Radyoterapi \%50 hastanın tedavisinde kullanılmıştır. Hipofizer tutulumlu bir hastamıza indüksiyonu 4 kür kladribin ile yapılmıştır. Tüm hastalar tam yanıtla remisyonda takiptedir Median takip süresi 59 ay ( en az 5 ay - en çok 100 ay ) 'dır.

TARTIŞMA ve SONUÇ: Erişkin başlangiçlı LHH nispeten iyi seyretmekte olup rezeksiyon, tutulu alan radyoterapisi, sistemik kemoterapi tedavi edilebilmektedir. Vinblastin ve steroid tedavisi sistemik tedavide ilk basamakta etkin ve güvenlidir.

Anahtar Kelimeler: Langerhans hücreli histiyositozis, vinblastin, erişkin başlangıç, kemik

\section{ABSTRACT}

INTRODUCTION: Langerhans cell histiocytosis is a group of diseases characterized by clonal neoplastic proliferation of atypical histiocytes in various tissues such as bone, pituitary gland, lymph nodes, lungs and central nervous system. The aim of this study was to evaluate in terms of clinical, laboratory and survival retrospectively and to examine the role of vinblastine chemotherapy in treatment.

METHODS: Eight cases included in our study between May 2011 and September 2019 and evaluated retrospectively.

RESULTS: The mean age of eight patients is 37 (youngest 19-largest 75). The male / female ratio is 7/1. The most common complaint of patients was bone pain at the rate of 50\%. In clinical staging, $62.5 \%$ patients had single system involvement, while $37.5 \%$ had multi-system involvement. In $60 \%$ of patients with a single system involvement, it was assessed in high risk class like central nervous system invasion due to location of involvement. Surgical resection for diagnostic purposes was also evaluated as a treatment in $25 \%$ patients with a single system involvement. As chemotherapy, vinblastine+ methylprednisolone treatment was preferred in $37.5 \%$ of the firt line treatment and $12.5 \%$ was fort he second line treatment. Radiotherapy has been used in the treatment of $50 \%$ of patients.Induction of a patient with pituitary involvement was performed with 4 cycles of cladribine. Median follow-up is 59 months (minimum 5 months - maximum 100 months). 
DISCUSSION AND CONCLUSION: The clinical course of Adult-onset Langerhans cell histiocytosis is relatively well and can be treated with resection, radiotherapy of involvement area, systemic chemotherapy. Vinblastine and steroid therapy is effective and safe in the first line of systemic therapy.

Keywords: Langerhans cell histiocytosis, vinblastine, adult onset, bone

\section{GíRiş}

Langerhans hücreli histiyositozis (LHH), nedeni bilinmeyen, atipik histiyositlerin lokal veyayaygın olarak kemik, cilt, hipofiz bezi, lenf nodları, karaciğer, dalak, oral mukoza, akciğerlerve merkezi sinir sistemi gibi çeşitli dokularda klonal neoplastik çoğalması ve osteolitik kemiklezyonları ile karakterize oldukça nadir görülen bir hastalık grubudur(1). LHH, histiyositozlarınlangerhans hücresi ilişkili alt grubunu oluşturmaktadır (2). Patogenezinde yer alan bu hücreler, cilt langerhans hücrelerine benzerliği nedeniyle 'Langerhans hücreleri' olarak isimlendirilmektedir ancak cilt yerine myeloid dendritik hücrelerden köken aldıkları bilinmektedir(3-6). Langerhans hücresi ilk defa 1868 'de Paul Langerhans tarafindan nonpigmente dendritik hücre olarak tanımlanmıştır(7). Bir çok bilim insanı Letterer-Siwe disease, Hand-Schüller-Christian disease, Histiocytosis-X gibi farklı isimlerle vakalarını tanımlasa da, Langerhans-hücreli histiyositoz (LHH) teriminin daha uygun olduğu düşünülmüş ve 1987 'deki sınıflamaya bu isimle girmiştir(2,7,8). LHH yıllık insidans1, erişkin hastalarda 1-2 /milyon olup erkeklerde daha sik rastlanılır (E/K: 3/1). Kuzey Avrupa ve Kafkaslarda daha sik, Asya ve Afrika'da daha nadir görülmektedir(7). Klinik ve radyolojik bulgular, çoğu hastada hastalık tanısinı destekler. Kesin tanı etkilenen dokunun patolojik incelemesi ile konur. Langerhans hücreleriyüzeylerinde CD1-a, CD207 (langerin) ve $\mathrm{S} 100$ proteinini ekspresyonuvardır(1,7). Tanı için immünhistokimyasal boyalarla CD1a, CD207 pozitifliği ya da elektron mikroskopta Birbeckgranüllerinin görülmesi gerekir(1). LHH hastalarının \%50`sinin doku örneklerinde BRAF (V600E) mutasyonu saptanmış ve BRAF mutasyonunun multisistemik tutulumlu vakalarda daha sık görüldüğü ve nüks riskinde artış ile ilişkili olduğu tespit edilmiştir(3,9). BRAF mutasyonu periferik kandan elde edilen DNA'dan PCR yöntemi ile sıvı biyopsi adı altında erken teşhis için güçlü bir araç olarak yerini korumaktadır(10). LHH, asemptomatik tutulumdan multisistem yaygin tutulumlara kadar değişik klinik tablolara yol açabilir. Özellikle karaciğer, dalak, kemik iliği tutulumu gibi organ tutulumlarında mortalite riski artmaktadır(3). Merkezimizde takip edilen sekiz LHH olgusunun klinik, laboratuvar ve sağkalım açısından retrospektif olarak değerlendirilmesi ve tedavide vinblastin kemoterapisinin rolünün incelenmesi amaçlanmıştır.

\section{METHOD- YÖNTEM}

Bu çalışmada, Mayıs 2011 -Eylül 2019 tarihleri arasında merkezimizde takip edilen sekiz LHH olgusu retrospektif olarak incelenmiştir. Hastaların tanı zamanı, semptom ve bulguları, klinik özellikleri, laboratuvar bulguları, radyolojik olarak gösterilen tutulum alanları, aldıkları tedaviler ve yanıtları hasta dosyalarından kaydedilmiştir.LHH tanısı, biyopsi örneklerinde yoğun langerhans hücresi, eozinofilik lökosit ve makrofaj infiltrasyonunun yanında, CD1-a ve S100 proteinini ekspresyonu immünhistokimyasal olarak gösterilmesi ile konuldu. Evreleme tutulum alanlarına göre radyolojik olarak bilgisayarlı tomografi (BT), manyetik rezonans görüntüleme (MRG) ve pozitron emisyon tomografisi(PET-BT) sonuçlarına göre yapıldı. Hastalar tutulum şekline göre Tablo 1'de verildiği şekilde sinıflandırıldı: Tek sistem tutulumu (tek bölge/çoklu bölge/özellikli bölge tutulumu) veya çoklu sistem tutulum riskli organ tutulumu vardır veya riskli organ tutulumu yoktur. Karaciğer, dalak ve hematopoietik sistem tutulumu riskli organ tutulumu olarak değerlendirildi. Hematopoietik sistem tutulumu kemik iliği tutulumu olsun 
veya olmasın anemi (demir eksiğine bağlı olmayan hemoglobin $<10 \mathrm{~g} / \mathrm{dL})$, lökopeni $(<4$ $\left.000 / \mathrm{mm}^{3}\right)$, trombositopeniden $\left(<100000 / \mathrm{mm}^{3}\right)$ en az ikisinin varlığında; karaciğer tutulumu midklaviküler hatta kostalmarjini $3 \mathrm{~cm}$ geçen hepatomegalide, başka nedenlere bağl1 olmayan hipoalbuminemide $(<2.5 \mathrm{~g} / \mathrm{dL})$ veya hipoproteinemide $(<5.5 \mathrm{~g} / \mathrm{dL})$; dalak tutulumu midklaviküler hatta kostalmarjini $2 \mathrm{~cm}$ geçen splenomegalide değerlendirildi (1,6,11).Kraniyofasiyal kemiklerde tutulum (Orbital, temporal, mastoid, sfenoid, zigomatik veya etmoidal kemiklerdeki lezyonlar); maksilla veya paranazal sinüslerdeki yumuşak doku kitleleri, kulak tutulumu, proptosis, ekzoftalmus gibi göz tutulumları, oral mukoza, diş etleri, damak, maksilla ve mandibula lezyonları, vertebraya komşuyumuşakdokulezyonlarının intraspinal bölgeye uzanması santral sinir sistemi tutulumu açısından riskli bölgeler olup fonksiyonel olarak kritik bölge tutulumları özellikli bölge tutulumu olarak değerlendirildi(1,6,11). Tedavilerin yanitı Uluslararası Histiyosit Çalışma Grubunun hastalık durumunu tanımlama kriterlerine göre değerlendirildi(11). Tedavi sonu hiç hastalık bulgusu yok, lezyonlar tamamen gerilemiş ise 'aktif hastalık yok'; yeni lezyon yok, eski lezyonlarda gerileme varsa 'regresif hastalık'; yeni lezyon yok, eski lezyonlar persiste ise 'stabil hastalık', lezyonlarda ilerleme var ve/veya yeni lezyonlar mevcut ise "progresif hastallk' olarak isimlendirildi(11). İstatistiksel analiz için SPSS 22.0 programı kullanıldı. Verileri özetlemek için tanımlayıcı istatistikler kullanıldı. Normal dağılım gösteren parametrik veriler ortalama \pm standart sapma verilerek belirtildi. Normal dağılım göstermeyen veriler ortanca veya yüzde olarak verildi.

\section{BULGULAR}

\section{Demografik özellikler:}

Merkezimizde 8 ylllık süreçte 8 hasta LHH tanısıyla izleme alındı. Sekiz hastanın ortalama yaşı 37 (aralık 19-75) dir. Erkek / kadın oranı $7 / 1^{\prime}$ dir. \%37 (n:3) hasta çiftçilikle uğraşmaktaydı. 1 hastanın ek olarak kronik obstruktif akciğer hastalığı mevcuttu, diğer 8 hastada kronik bir hastalık eşlik etmiyordu. Hiçbir hastanın soygeçmişinde ek başka malignite yoktu. \%25 (n:2) hastada sigara öyküsü mevcuttu. Hastaların tanı sırasındaki klinik sınıflaması ve genel özellikleri tablo 2'de verilmiştir.

\section{Semptom bulgu ve klinik özellikler:}

Hastaların en sık başvuru şikayeti \%50 oranında ( n:4 hasta ) kemik ağrısı oldu. Diğer görülen başvuru semptomları \%37 hareket kısıtlılığ1 (n:3 hasta), \%25 kaşıntı (n:2), \%25 lenf nodu büyümesi (n:2), \%12 egzoftalmus (n:1), \%12 başağrısı (n:1), \%12 poliüri ve polidipsi (n:1) , \% 12 cilt lezyonları (n:1), $\% 12$ ateş yüksekliği (n:1)oldu. Hastaların tutulu alanlarına göre klinik evrelemesinde $\% 62$ 'sinin tek sistem tutulumu olduğu (n:5); bunların \%60'ının tek bölgede(n:3), \%40'ının multifokal olduğu (n:2) görüldü. Tüm hastaların \%37'sinin multi-sistem tutulumu saptandığı (n:3); bunlarında \%66'sın da riskli organ tutulumu (kemik iliği) olduğu (n:2) görüldü. Tek sistem tutulumlu hastaların $\% 60$ 'nnda tutulum yeri nedeniyle santral sinir sistemi invazyonu açısından riskli bölgelere yerleştiği görülerek yüksek risk sınıfında (n:3) değerlendirilmiştir(Tablo 1). Organ tutulumları incelendiğinde $\% 75$ oranında (n:6) kemik tutulumu olduğu görüldü. Tanıda en çok tutulan kemikler; kalvarium ve pelvis olmuştur. Kalvaryum kemiklerinden de en çok orbital kemik, frontoparietal ve temporofrontal kemikler tutulmuştur. Bir hastamızda poliüri ve polidipsi şikayetlerinin hipotalamohipofizer bölgede tutuluma bağlı diabetes insipitus'a(DI) bağlı olduğu düşünülmüştür. Tanı laboratuvar değerleri incelendiğinde ortalalama hemoglobin $15.3 \mathrm{gr} / \mathrm{dl}$, ortalama beyaz küre sayısı $6.7 / \mathrm{L}$, ortalama trombosit sayisının $266 / \mathrm{L}$, ortalama sedimentasyon 24.8 $\mathrm{mm} / \mathrm{saat}$, ortalama LDH $207 \mathrm{U} / \mathrm{L}$ olarak normal sınırlar içerisinde oldukları görüldü. Cilt tutulumu ile seyreden bir hastamıda eozinofili ve immnüglobulin $\mathrm{E}$ yüksekliği saptandi. 


\section{Radyolojik özellikler}

Hastalarin \%75'ine MRG (n:6), \%37'sine PET-BT (n:3), \%37'sine BT(n:3), \%12'sine kemik sintigrafisi (n:1) çekildi. Kranial kemikleri ve intrakranial patoloji görüntülemek için en sık kranial MRG kullanıldı. PetBT ile tanı evrelendirmesi yapılan hastalarda Suvmax tutulumlarının düşük olduğu görüldü (suv-max 3.6-5.7). Pet-BT ile kemiklerde litik lezyonlar görüldü. 1 hastada böbrekte $43 \times 22$ mm tutulum saptandı ancak böbrek biyopsisi tanısal bir sonuç vermedi. Kemik ağrısı nedeniyle ortopediye başvuran $\% 12$ hastada tüm vücut kemik sintigrafisinin de çekildiğ $i$ görüldü.

\section{Tedavi özellikleri}

Hastalara verilen tedaviler tablo 3'te gösterilmiştir. Multisistem hastalıkta ve santral sinir sistemi (SSS) invazyonu açısından riskli tutulumu olanlarda sistemik tedavi ön plana çıkmıştır. Tanı amaçlı cerrahi rezeksiyon, tek sistem tutulu \%25 hastada tedavi olarak da değerlendirilmiştir. Kemoterapi olarak ilk basamakta \%37.5 (n:3) hastada, vinblastin + metilprednizolon tedavisi tercih edilmiştir. Bir hastada cerrahi rezeksiyon sonrasinda progresyon saptanması nedeniyle vinblastin + metilprednizolon tedavisine geçilmiş, idame tedavisinden 6 ay sonra lombervertebradanüks sebebiyle cerrahi ve radyoterapi uygulanmıştır. Radyoterapi \%50 hastanın (n:4) tedavisinde kullanılmıştır. Kranialkemik lezyonlarına yakın hipofizer tutulumlu bir hastamıza indüksiyonu 4 kür kladribin ile yapılmış, 5 yıl talidomid ile idame tedavisi verilmiştir. Diyabetes insipitus öyküsü nedeniyle nedeniyle tedavisine desmopressin eklenmiştir. İki hastada vinblastine bağlı nöropati izlenmiştir. Tedavi surasında kladribin bir hastada grade $3 / 4$ hematolojik toksisite görülmüştür. Kemiklerde litik lezyonu olanlara bifosfonat tedavisi verilmiştir.

Tablo 3 Hastalara verilen tedavi, yanıtları ve takibi

\begin{tabular}{|c|c|c|c|c|c|}
\hline Hasta & Klinik sınıflaması & Tedavi & Yanitı & $\begin{array}{l}\text { Yanit } \\
\text { süresi }\end{array}$ & Nüks \\
\hline 1. & $\begin{array}{l}\text { Multisistem ,riskli organ } \\
\text { tutulumu var }\end{array}$ & $\begin{array}{l}1200 \text { cGy RT, } \\
\text { 4kür vinblastin } \\
6 \text { hafta prednol }\end{array}$ & $\begin{array}{l}\text { Tam } \\
\text { yanit }\end{array}$ & $5 \mathrm{AY}$ & \\
\hline 2. & $\begin{array}{l}\text { Multisistem,riskli organ } \\
\text { tutulumu yok }\end{array}$ & $\begin{array}{l}\text { 6kürvinblastin } \\
6 \text { hafta prednol }\end{array}$ & $\begin{array}{l}\text { Tam } \\
\text { yanit }\end{array}$ & $5 \mathrm{AY}$ & \\
\hline 3. & $\begin{array}{l}\text { Tek sistem tutulumu, tek } \\
\text { bölge, } \\
\text { SSS tutulumu açısından } \\
\text { özellikli bölge }\end{array}$ & $\begin{array}{c}6 \text { kürvinblastin } 6 \text { hafta } \\
\text { prednol } \\
\text { İdame : } 6 \text { kür } \\
\text { vinblastin+ prednol }\end{array}$ & $\begin{array}{l}\text { Tam } \\
\text { yanit }\end{array}$ & $61 \mathrm{AY}$ & \\
\hline 4. & $\begin{array}{l}\text { Tek sistem tutulumu, tek } \\
\text { bölge tutulumu }\end{array}$ & Cerrahi eksizyon & $\begin{array}{l}\text { Tam } \\
\text { yanit }\end{array}$ & $48 \mathrm{AY}$ & \\
\hline 5. & $\begin{array}{l}\text { Tek sistem tutulumu, } \\
\text { multifokal, } \\
\text { SSS tutulumu açısından } \\
\text { özellikli bölge }\end{array}$ & Cerrahi rezeksiyon & $\begin{array}{l}\text { Tam } \\
\text { yanit }\end{array}$ & $96 \mathrm{AY}$ & $\begin{array}{l}\text { 1.Nüks: 6Kürvinblastin } \\
6 \text { Hafta Prednol, idame } 12 \\
\text { Hafta Vinblastin + Prednol } \\
\text { 2.nüks: cerrahi }+2500 \mathrm{~Gy} \\
\text { Radyoterapi }\end{array}$ \\
\hline 6. & $\begin{array}{l}\text { Tek sistem tutulumu, } \\
\text { multifokal tutulumu }\end{array}$ & Cerrahi rezeksiyon & $\begin{array}{l}\text { Tam } \\
\text { yanit }\end{array}$ & $57 \mathrm{AY}$ & \\
\hline 7. & $\begin{array}{l}\text { Tek sistem tutulumu, tek } \\
\text { bölge, } \\
\text { SSS tutulumu açısından } \\
\text { özellikli bölge }\end{array}$ & Cerrahi rezeksiyon+RT & $\begin{array}{l}\text { Tam } \\
\text { yanit }\end{array}$ & $71 \mathrm{AY}$ & \\
\hline 8. & $\begin{array}{l}\text { Multisistem,riskli organ } \\
\text { tutulumu var }\end{array}$ & $\begin{array}{c}\text { 4kürKladribin } \\
+5 \text { y1l Talidomididame } \\
+ \text { Sol FemuraRT+2y1l } \\
\text { Zoledronikasit }\end{array}$ & $\begin{array}{c}\text { Tam } \\
\text { yanit }\end{array}$ & $100 \mathrm{AY}$ & \\
\hline
\end{tabular}

SSS:santral sinir sistemi RT: radyoterapi 


\section{Takip ve sonuçlar}

Hastaların tamamı cerrahi veya sistemik kemoterapiye tam yanıt vermiştir. Bir hastada 2 kez progresyon görülmüştür, tedaviler sonrası tam yanıt elde edilmiştir. Tüm hastalar tam yanitla remisyonda takiptedir (aktif hastalık yok ). Median takip süresi 59 ay (en az 5 ay - en çok 100 ay )'dır.

\section{TARTIŞMA}

Langerhans hücreli histiyositozis nadir görülen bir hastalık grubudur ve daha çok pediatrik yaşta tanı alır. $\mathrm{Bu}$ nedenle literatürde erişkin başlangıçlı LHH verilerinin daha çok vaka serileri olarak yayınlandığını görüyoruz $(7,9,12)$ Biz de çalışmamızda merkezimizde takipli LHH hastalarımızın 8 yıllık klinik seyir ve tedavi yantlarını değerlendirerek literarüre katk1 sağlamayı amaçladık. LHH asemptomatik seyirden multisistem tutulumlarına kadar çeşitli bir yelpazede klinik göstermektedir. Morimoto ve arkadaşlarının çalışmasında da belirtildiği gibi LHH' da lezyonlar sadece langerhans hücreleri içermez(1). Mikroçevreyle ve diğer hücrelerle ilişki halinde olan $\mathrm{T}$ lenfositler, makrofajlar, plazma hücreleri, osteroklast benzeri multinükleer dev hücreler, nötrofiller gibi inflamatuvar hücreler ve salgıladıkları Granulocyte Macrophage Colony-Stimulating Factor(GM-CSF), interferon (IFN)- $\gamma$, tumor necrosis factor (TNF)- $\alpha$, interlökin (IL)- $1 \alpha$, IL2, IL-3, IL-4, IL-5, IL-7 ve IL-10 gibisitokinler mevcuttur. $\mathrm{Bu}$ sitokin-kemokin firtınas1 ve çevre hücrelerle ilişkisi LHH klinik seyrini belirlemektedir (1). Biz de hastalarımızdaki tanı anı tutulum organlarını değerlendirdiğimizde çeşitli organ tutulumları saptadık. Organ tutulumları incelendiğinde \%75 oranında kemik tutulumu olduğu görüldü. $\mathrm{Bu}$ oran literatürde belirtilen $\% 80$ oranıla uyumlu saptanarak, en çok da kalvarium tutulumu görüldü $(1,6,13)$.Çalışmamızın Epidemiyolojik verileri literatürle karşılaştırıldığında erişkinlerde görülme yaşının dördüncü dekat olmasının ve erkek cinsiyet hakimiyetinin oldukça benzer olduğu görüldü(6). Ancak erişkinlerde daha sik görülen pulmoner tutulum bizim hasta grubumuzda hi çizlenmedi. Bu bulgu bizim hasta grubumuzda sigara içme oranını düşük olmasıyla ilişkilendirilebilir.

Tedavi yaklaşımları hastalığın klinik sınıflaması ve riskli tutulumlarına gore yapılmaktadır(6,14). Tek system tek bölge tutulumları cerrahi rezeksiyonla tedavi edilirken çoklu bölge tutulumları tek prednizolon ya da vinblastinle kombinasyonu tercih edilebilir. Multi system tutulumlar ya da unifokal tutulumla birlikte SSS için riskli tutulumlar sistemik kemoterapilerle tedavi edilmektedir(6). Genel yaklaşım birinci basamakta 6 haftalık vinblastin ve prednizolon ile indüksiyon yönündedir ancak bu konuda tam bir standart yaklaşım belirlenmemiştir. 2017'de Tazi ve arkadaşlarının yaptığı sistemik tedavi endikasyonu olan 35 erişkin hastay1 içeren çok merkezli retrospektif çalışmada, akciğer tutulumu dişında birinci basamakta vinblastin- metilprednisolon uygulamasına, erişkin hastaların aynı çocuk hastalardakine benzer şekilde iyi yanıt verdiği ve iyi tolere edildiği görülmüştür(13).Erişkin yaşta başlayan LHH'de kemik lezyonlarının bitişik olduğu MSS tutulumu, karaciğer,dalak,kemik iliği tutulumu gibi riskli organ tutulumu olan hastalarda da vinblastinsteroid tedavisinin etkili ve tolere edilebilir birinci basamak tedavisi olduğu düşünülmüştür(13). Tazi ve arkadaşlarınınyaptı̆̆ 1 retrospektif çalışmada akciğer dışı riskli organ tutulumu olan hastalarda vinblastin-steroid tedavisinin $\% 71$ yanıt oranı ile tolere edilebilir ve etkili birinci basamak tedavi olarak kullanılabileceği gösterilmiştir(13). Vinblastin ve steroid, temel olarak kemik hastalığı olan hastalarda kullanılan bir tedavidir $(13,15)$; ancak yüksek riskli grupta mercaptopürin eklenebilir(15). Myeloid malignitelerde etkili olan nükleozid analoglarının da(sitarabin, kladribin, veklofarabin) LHL' da etkili olduğu bilinmektedir(16,17). Erişkin yaşta başlayan ve akciğer tutulumunun olduğu LHH'da 
vinblastin-steroid tedavisinin birinci basamak tedavi olarak kullanılması uygun olmayıp, bu durumda kladribin tedavisi umut vaad etmektedir(18).Saven ve arkadaşlarının çalışmasında kladribin tedavisi ile hem tek sistem multifokal tutulum gösteren ve hem de multisistem tutulumlu hastalarda \%75 yanit alınmıştır(19). Kladribine SSS kitle lezyonlarında da etkilidir(20). Merkezimizde yapilan retrospektif incelemede, kranial kemik lezyonları ve hipofizer tutulumlu bir hastamıza kladribin tedavisi uygulanmış olup, halen tam remisyonda olarak 100 aytakip edilmiştir.

LHH 'de nüks etme eğilimi önemli bir problemdir.Riskli organ tutulumunun olması reaktivasyon riski taşır ve prognozu olumsuz olarak etkilemektedir(13). İkinci reaktivasyonunda kemik lezyonlarının bitişik olduğu SSS tutulumu ile gelen diğer hastamıza vinblastin-steroid tedavisi verildi ancak 6 ay içinde lomber vertebradan progrese olarak cerrahi ve radyoterapi tedavisi aldi. Riskli organ olarak kemik iliği tutulumu olan bir hastamıza yine vinblastin-steroid tedavisi başlanmış olup tam remisyonda izlenmektedir. Lokalize cilt tutulumu ile başlayıp yaygınlaşan ve multipl LAP tutulumlarının eşlik ettiği 75 yaşındaki hastamızın tedavisine vinblastinsteroid ile başlanmış olup tam yanıtla izlenmektedir. Retroorbital kitlesi olan hastamıda vinblastin-steroid tedavisi ile 61 aydır remisyonda izlenmektedir. Tazi ve arkadaşlarının yaptığı çalışmaya göre riskli organ tutulumu olmayan hastalarda 5 yıllık nüks oranının $\% 37,5$ olduğu görülmüştür. Ancak çalışmamızda riskli organ tutulumları dahil \%12 hastada reaktivasyon nedeniyle tedavi alarak literatüre oranla iyi bir hastalık kontrolü elde edilmiştir. Yan etki profilline bakıldığında kladribin tedavisi uygulanan SSS tutulumu olan hastamızda uzun süren grade 3/4 myelosupresyon gelişmiş, vinblastin-steroid tedavisi verdiğimiz hastalarımızın ikisinde periferiknöropati ve bir hastada kontrol altına alınabilen konstipasyon dışında yan etki saptanmamıştır.

Son yıllarda hastalık patofizyolojisinin daha iyi anlaşılması sonucu yeni tedavi hedefleri de keşfedilmiştir. Normal şartlarda hücre içi MAPK yolağı hücre büyümesi, farklılaşması ve hayatta kalmasının transkripsiyonel programlarını düzenleyen hücre içi sinyal yolağıdır ve LHH 'da bu yolak disregüledir(6). Tüm malignitelerin $\% 8$ inde BRAFV600E mutasyonu tanımlanır(6).LHH hastalarının ise $\% 50$ 'sinin doku örneklerinde BRAF V600E mutasyonu saptanmış ve BRAF mutasyonunun multisistemik tutulumlu vakalarda daha sik görüldüğü ve nüks riskinde artış ile ilişkili olduğu tespit edilmiştir(7). Çalışmamızdaki hastalarda BRAF V600E mutasyonu değerlendirmek mümkün olmamıştır. MAPK ve BRAF V600E inhibisyonu uygun hastalarda tedavi hedefi olarak kullanılabilir. BRAF V600 e inhibisyonu yapan ve murafenibre indüksiyon tedavisinde etkinliği gösterilmiştir(10,21).

Sonuç olarak, erişkin başlangıçlı LHH olarak vinblastin ve steroid tedavisi ilk basamak tedavide etkili ve tolere edilebilir gözükmektedir. Multisistem ve riskli tutulum organları varllğında vinblastinprednol 6 haftalık tedavisi öncelikli tercih edilmiştir. Pulmoner ve SSS tutulumlarında kladribin göz önünde bulundurulmalıdır. LHH etyopatogenezindeki moleküler mekanizmalar anlaşıldıkça, hücre içi sinyallerini azaltacak yeni hedefe yönelik tedaviler artacaktır.

\section{Referanslar:}

1. Morimoto A, Oh Y, Shioda Y, Kudo K, Imamura $\mathrm{T}$. Recent advances in Langerhans cell histiocytosis. Pediatr Int. 2014;56(4):451-61.

2. Abla O, Fraitag S, Horne A,et al. Review Article

Revised classification of histiocytoses and neoplasms of the macrophage-dendritic cell lineages. Blood. 2016;127(22):2672-82.

3. Rahrotaban S, Mahdavi N, Derakhshan S, Jahromi MN. Langerhans cell histiocytosis. Koomesh. 2019;21(3):576-8. 
4. Krooks J, Minkov M, Weatherall AG. Langerhans cell histiocytosis in children: History, classification, pathobiology, clinical manifestations, and prognosis. J Am Acad Dermatol 2018;78(6):1035-44.

5. Mazlum A, Ceylan B, Güngör K, Ceylan Ş. Langerhans hücreli histiyositoz. 2004;16(10):57-61.

6. Rodriguez-Galindo C, Allen CE. Langerhans cell histiocytosis. Blood. 2020;135(16): 131931.

7. Kobayashi M, Tojo A. Langerhans cell histiocytosis in adults: Advances in pathophysiology and treatment. Cancer Sci. 2018;109(12):3707-13.

8. The Writing Group of the Histiocyte. Histiocytosis Syndromes In Children. Lancet. 24 Ocak 1987;329(8526):208-9.

9. Berres ML, Lim KPH, Peters T,et al. BRAF$\mathrm{V} 600 \mathrm{E}$ expression in precursor versus differentiated dendritic cells defines clinically distinct LCH risk groups. J Exp Med. 2014;211(4):669-83.

10. Héritier S, Emile JF, Barkaoui MA,et al. BRAF Mutation Correlates With High-Risk Langerhans Cell Histiocytosis and Increased Resistance to First-Line Therapy. J Clin Oncol. 2016;34(25):3023-30.

11. Rodriguez-galindo C, Simonitsch-klupp I. Langerhans Cell Histiocytosis Histiocyte Society Evaluation and Treatment Guidelines. 2009;(April).

12. Giona F, Caruso R, Testi AM, et al. Langerhans' cell histiocytosis in adults: A clinical and therapeutic analysis of 11 patients from a single institution. Cancer. 1997;80(9):1786-91.

13. Tazi A, Lorillon G, Haroche J, et al. Vinblastine chemotherapy in adult patients with langerhans cell histiocytosis: a multicenter retrospective study. Orphanet J Rare Dis. 2017;12(1):1-10.

14. Milen M. Multisystem Langerhans Cell Histiocytosis in Children. Paediatr Drugs. 2011;13(2):75-86.

15. Gadner H, Minkov M, Grois N,et al. Therapy prolongation improves outcome in multisystem Langerhans cell histiocytosis. Blood. 2013;121(25):5006-14.

16. Abraham A, Alsultan A, Jeng M, Rodriguezgalindo C, Campbell PK. Clofarabine Salvage Therapy for Refractory High-Risk Langerhans Cell Histiocytosis. Pediatr Blood Cancer. 2013;(November 2012):E19-E22.

17. Rodriguez-galindo C, Kelly P, Jeng M, Presbury GG, Rieman M, Wang W. Treatment of Children With Langerhans Cell Histiocytosis With 2-Chlorodeoxyadenosine. 2002;184(April 2001):179-84.

18. Grobost V, Khouatra C, Lazor R, Cordier J, Cottin V. Effectiveness of cladribine therapy in patients with pulmonary Langerhans cell histiocytosis. 2014;1-8.

19. Saven A, Burian C: Cladribineactivity in adultlangerhans-cellhistiocytosis. Blood 1999, 93(12):4125-4130

20. Dhall G, Finlay JL, Dunkel IJ,et al. Analysis of Outcome for Patients With Mass Lesions of the Central Nervous System Due to Langerhans Cell Histiocytosis Treated With 2Chlorodeoxyadenosine. 2008; (September 2006):72-9.

21. Haroche J, Cohen-aubart F, Arnaud L, et al. Dramatic efficacy of vemurafenib in both multisystemic and refractory ErdheimChester disease and Langerhans cell histiocytosis harboring the BRAF V600E mutation. 2013;121(9):1495-500 